\title{
Phalaris paradoxa L. (Poaceae: Phalaridinae), a new introduced weed species in Central Chile
}

\section{Phalaris paradoxa L. (Poaceae: Phalaridinae), nueva maleza introducida en Chile central}

\author{
Víctor L. Finot \& J. Alberto Pedreros \\ Facultad de Agronomía, Universidad de Concepción, Casilla 537, Chillán, Chile. \\ vifinot@udec.cl
}

\section{RESUMEN}

Se da a conocer la presencia de Phalaris paradoxa L. (Poaceae), nueva especie para la flora advena de Chile, recolectada como maleza de cultivos agrícolas en la Región del Libertador Bernardo O’Higgins, 34³9'S, 71²3'W. Se incluye una clave para determinar las especies de Phalaris que crecen en Chile.

The genus Phalaris L. comprises 22 species (Baldini 1995, Barkworth et al. 2007), seven or eight of which are present in Chile, including P. paradoxa L., new to the Chilean flora: $P$. amethystina Trin., $P$. angusta Nees ex Trin., $P$. aquatica L., $P$. arundinacea L., $P$. canariensis L., $P$. minor Retz. and $P$. paradoxa $\mathrm{L}$. In addtion, $P$. caroliniana Walter, a species closely related to $P$. amethystina, has been cited for Chile (Marticorena \& Quezada 1985). Nevertheless, the presence of $P$. caroliniana in Chile needs to be confirmed, because all the revised herbarium specimens collected in Chile may be assigned to $P$. amethystina.

Phalaris includes annual or perennial grasses with terminal spiciform panicles composed of spikelets that borne singly or in clusters. The spikelets are usually 3flowered, with one terminal perfect floret and two sterile florets below; the two lower sterile lemmas are absent or much reduced in $P$. paradoxa and related species. Most of the species of Phalaris are native to temperate zones of the Northern Hemisphere, with two distribution centers: one in the Mediterranean region of Europe and another in the Southwest of the United States (Baldini 1995, Tucker 1996).

Phalaris angusta and $P$. amethystina are the only two species native to Chile; the remaining species are all adventitious (Parodi 1939, 1943; Marticorena \& Quezada 1985). Desvaux (1854) in his treatment of the Gramineae included four species: $P$. angusta, $P$. canariensis, $P$. microstachys DC. (= P. caroliniana) and P. chilensis (= P. angusta). Parodi (1939, 1943) mentions four species: $P$. amethystina, $P$. angusta, $P$. canariensis and $P$. tuberosa var. stenoptera ( $=P$. aquatica). Marticorena \& Quezada (1985) recognized five species for Chile: $P$. amethystina, $P$. angusta, P. aquatica, P. caroliniana and P. minor. Recently,
Zuloaga et al. (2008) mention for Chile six species: $P$. amethystina, $P$. angusta, $P$. aquatica, $P$. canariensis, $P$. caroliniana and $P$. minor. To this list we have to add $P$. arundinacea cultivated in Southern Chile but also collected in the wild between Chiloé and Magallanes.

Phalaris paradoxa L., Sp. P1. (ed. 2) 2: 1665. 1763. Type: Habitat in Oriente, Forsskal s.n. (LINN 78.6), lectotype designated by Baldini \& Jarvis, Taxon 40: 483. 1991.

For a complete synonymy see Baldini (1995).

ICONOGRAPHY. Hitchcock, A.S. 1950: 552, fig. 797; Barkworth et al. 2007: 425.

COMMON NAMES. Hood canary grass, hooded canary grass, bristle-spiked canary grass.

Annuals, erect or decumbent. Culms 30-50 (-100) cm tall, glabrous. Leaf sheaths striate, glabrous, shorter than the internodes, often reddish; ligule hyaline ca. $5 \mathrm{~mm}$ long; leaf blades flat, 100-150 x 3-5(-7) mm, glabrous. Panicle dense, oblong, (2-)3-7 x 2-3 cm, green tinged with purple, narrowing towards the base, often included in the uppermost sheath. Spikelets clustered in groups of 7; clusters composed of 1 central fertile spikelet surrounded by 6 sterile spikelets. Fertile spikelet 5.5-8 mm long.; glumes 7-9-nerved, winged on the keel, the keel with a prominent triangular tooth near the upper third, the apex subulate-acuminate to aristate; fertile lemma $3 \mathrm{~mm}$ long., muticous; sterile lemmas absent or very reduced; stamens 3 . Sterile spikelets shorter, with narrower glumes, the glumes with toothed-winged keels. Cariopsis $3 \mathrm{~mm}$ long. 2n=14 (Baldini 1995). 
Distribution. Native to the Mediterranean region of Europe is currently found worldwide (Barkworth et al. 2007). In North America is a weed in Arizona, California, and Washington (Hitchcock 1950, Barkworth et al. 2007). In South America it was cited by Renvoize (1998) for Bolivia (La Paz). Zuloaga et al. (2008) mention P. paradoxa for Argentina (Buenos Aires, Corrientes, Entre Ríos, Santa Fe) and Uruguay (Montevideo).

ECOlOGy AND habitat. Plants of $P$. paradoxa were collected in fields cultivated with onion (Allium cepa L.), cabbage (Brassica oleracea var. capitata L.) and pea (Pisum sativum L.), on clay soil. It grows also abundantly on the edge of an irrigation channel, associated to Brassica rapa L., Capsella bursa-pastoris (L.) Medik., Cirsium vulgare (Savi) Ten., Erodium moschatum (L.) L'Hérit. ex Aiton, Geranium corecore Steud., Ranunculus muricatus L., Senecio vulgaris L., Silybum marianum (L.) Gaertn., Digitaria sanguinalis (L.) Scop. and several other grass species. During the collection time (August) plants were found in vegetative state as well as in full bloom (Fig. 1A-D).

Comments. The only weed species belonging to genus Phalaris previously mentioned for Chile is $P$. aquatica (Matthei 1995). Holm et al. (1979) cited P. paradoxa as a weed for 25 countries. In Europe it was early recognized as a weed of agricultural fields, especially in cereal crops (Dunn 1905). Dimitri (1978) notes its presence in flax and grain crops in Argentina. It was also introduced in Australia (Walker et al. 2002) and Israel (Yaacobi et al. 1986, Schönfeld et al. 1987), where it grows mainly as a weed of cereal fields. According to Horowitz (1980), P. paradoxa was cited as a noxious weed in Israel more than 50 years ago and was still a serious problem in 1980. Yaacobi et al. (1986) and Schönfeld et al. (1987) found biotypes resistant to triazine herbicides in Israel. Resistant biotypes survived applications of $4 \mathrm{~kg}$ ia/ha of atrazine applied in pre and postemergence and to metribuzine. Besides, $P$. paradoxa has been cited as resistant weed to ACCase inhibitor herbicides (Heap 2011, Senseman 2007).

Diagnostic Characters. Spikelets in clusters; the upper central fertile spikelet surrounded by six lower sterile spikelets (sect. Heterachne Dum.); glumes keeled, winged, with a conspicuous dorsal tooth in the upper third (Fig. 1E-G).

Studied material. Chile, Región del Libertador Bernardo O'Higgins, Santa Cruz, camino Santa Cruz - Lolol, km 6 por carretera $172,34^{\circ} 39^{\prime} \mathrm{S}, 71^{\circ} 23^{\prime} \mathrm{W}, 155 \mathrm{~m}$ s.m., 26-VIII2011, V.L. Finot 2515 (CONC, CONC-CH).

In order to contribute to the identification of the species of genus Phalaris in Chile, the following key is provided.

\section{Key to species of Phalaris in Chile}

1. Spikelets heterogamous, borne in clusters of 7, one central fertile spikelet surrounded by six sterile spikelets; glumes with acuminate or aristate apex, winged and with a dorsal tooth in the upper third

P. paradoxa

1 '. Spikelets homogamous borne singly, all fertile.

2. Plants perennial.

3. Panicle spiciform 5-15 cm long, not expanding at anthesis; basal internodes sub-bulbous; glumes winged ...........P. aquatica

3'. Panicle not spiciform 5-20 cm long., lobed, dense or interrupted below, expanding at anthesis, the lower branches to $5 \mathrm{~cm}$ long.; rhizomes present; glumes not winged

2'. Plants annual.

4. Glumes not winged or with a very narrow wing.

5. Glumes scabrous, with a strongly scabrous prominent midrib; panicle narrow, linear, up to $20 \mathrm{~cm}$ long.; spikelets 2-3flowered, 2.5-5.0 mm long.; fertile lemma 2.8-3.2 mm long.; sterile lemmas 0.5-1.5 mm long, pilose .................P. angusta 5'. Glumes not scabrous, without a scabrous prominent midrib; panicle subovoid, 1.0-7.5 cm long.; spikelets 3-flowered, 5.0$6.5 \mathrm{~mm}$ long.; fertile lemma 2.9-3.4 mm long.; sterile lemmas 1.1-2.0 mm long., glabrous P. amethystina

4'. Glumes broadly winged.

6. Spikelets 2-flowered, 5.0-5.6 mm long.; fertile lemma 3.0-3.5 mm long.; sterile lemma 1.0-1.1 mm long., reaching 1/3

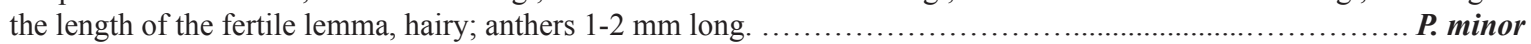
6'. Spikelets 3-flowered, 5.0-8.0 mm long.; fertile lemma 4.7-5.5 mm long.; sterile lemmas 2.5-3.5 x 0,5 mm, reaching about $1 / 2$ the length of the fertile lemma, subglabrous or sparsely hairy; anthers 3-4 mm long......

P. canariensis 

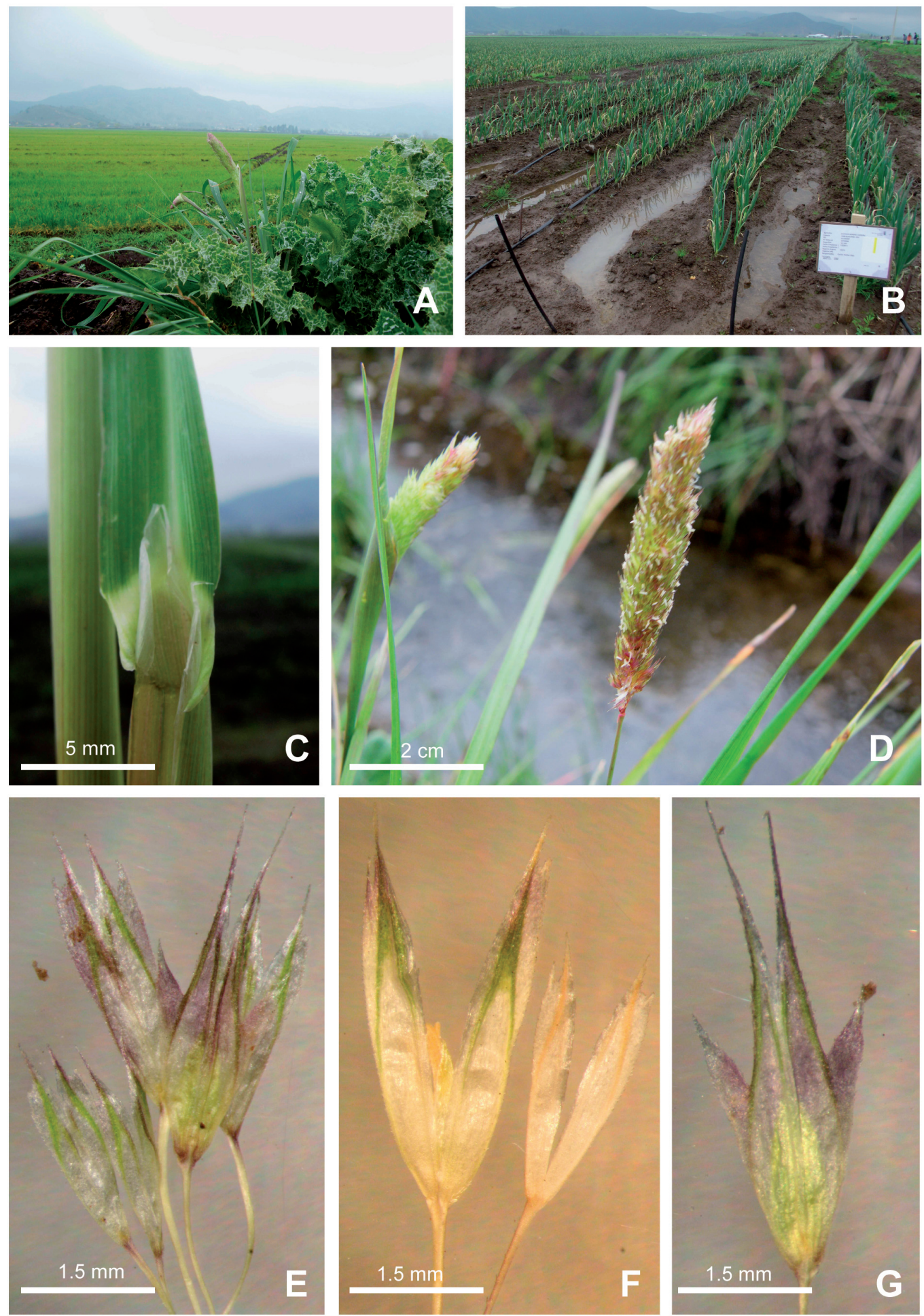

Figure 1. A-B. Onion crop at Santa Cruz, Region of O'Higgins infested with Phalaris paradoxa. C. Ligule. D. Panicles of P. paradoxa plants growing on the edge of irrigation channel. E. Cluster of spikelets. F. Fertile (left) and sterile (right) spikelets. G. Fertile spikelet showing triangular dorsal teeth in the middle of the wings.

Figura 1. A-B. Cultivo de cebolla en Santa Cruz, Región de O’Higgins, infestado con Phalaris paradoxa. C. Lígula. D. Panículas de plantas de P. paradoxa creciendo a orillas de un canal de regadío. E. Grupo de espiguillas. F. Espiguillas fértil (izquierda) y estéril (derecha). G. Espiguilla fértil mostrando los dientes triangulares en la zona media de las alas. 


\section{ACKNOWLEDGMENTS}

Authors thanks to Marcelo Baeza, who kindly sent us bibliography and Gustavo Moreno, who provided facilities for collecting plants. Project DIUC 210.121.014-1.0.

\section{BIBLIOGRAPHY}

BALDINI, R.M. 1995. Revision of the genus Phalaris L. (Gramineae). Webbia 49: 265-329.

BALDINI, R.M. \& C.E. JARVIS. 1991. Typifications of some Linnaean names in Phalaris (Gramineae). Taxon 40: 475-485.

Barkworth, M.E., L.K. Anderton, K.M. Capels, S. Long \& M.B. PIEP. 2007. Manual of grasses for North America. Intermountain Herbarium and Utah State University Press, U.S.A. 640 pp.

Desvaux, E. 1854. Gramíneas, en C. Gay, Historia Física y Política de Chile, Botánica 6: 233-469.

Dimitri, M.J. 1978. Enciclopedia argentina de agricultura y jardinería. Tomo I. Descripción de las plantas cultivadas. $3^{a}$ edición. Ed. ACME S.A.C.I., Buenos Aires. 851 pp.

DunN, S.T. 1905. Alien flora in Britain. West, Newman \& Co., London. 208 pp.

HEAP, I. 2011. The International Survey of Herbicide Resistant Weeds. www. weedscience.com. Accessed 18 Sept. 2011.

Hiтснсоск, A.S. 1950. Manual of the grasses of United States. United States Department of Agriculture, Washington DC. $1051 \mathrm{pp}$.

Holm, L.R., J.V. Pancho, J.P. Herberger \& D.L. Plucknett. 1979. A geographical atlas of world weeds. Wiley-Interscience, J. Wiley \& Sons, New York. 391 pp.
Horowitz, M. 1980. Weed research in Israel. Weed Science 457460.

Marticorena, C. \& M. Quezada. 1985. Catálogo de la flora vascular de Chile. Gayana Botánica 42(1-2): 1-147.

Matthei, O. 1995. Manual de las malezas que crecen en Chile. Alfabeta Imp., Santiago de Chile. 545 pp.

PArodi, L.R. 1939. El género Phalaris en Chile. Revista Argentina de Agronomía 6: 77-84.

PArodi, L.R. 1943. Las especies del género Phalaris de la flora chilena. Revista Chilena de Historia Natural 45: 130-136.

Renvoize, S.A. 1998. Gramíneas de Bolivia. Royal Botanic Gardens, Kew, England. 642 pp.

Schönfeld, M., T. YaAcobi \& B. Rubin. 1987. Triazine resistance without reduced vigor in Phalaris paradoxa. Plant Physiology 83: 329-333.

Senseman, S.A. 2007. Herbicide Handbook. Ninth Edition, Weed Science Society of America. Lawrence, KS. U.S.A. 458 pp.

Tucker, G.C. 1996. The genera of Pooideae (Gramineae) in the Southeastern United States. Harvard Papers in Botany 9: 11-90.

Walker, S.R., R.W. Medd, G.R. Robinson \& B.R. Cullis. 2002. Improved management of Avena ludoviciana and Phalaris paradoxa with more densely sown wheat and less herbicide. Weed Research 42: 257-270.

YAACoBi, T., M. SchÖNFEld \& B. RuBin. 1986. Characteristics of atrazine-resistant biotypes of three grass weeds. Weed Science 34: 181-184

Zuloaga, F.O., O. Morrone \& M. Belgrano. 2008. Catálogo de las plantas vasculares del Cono Sur. Vol. 1: Pteridophyta, Gymnospermae, Monocotyledoneae. Monographs in Systematic Botany 107, Missouri Botanical Garden Press, St. Louis, Missouri, U.S.A. 1-983.

Recibido: 23.09.11

Aceptado: 01.12.11 